\title{
Extraordinary blowing snow transport events in East Antarctica
}

\author{
Claudio Scarchilli $\cdot$ Massimo Frezzotti \\ Paolo Grigioni · Lorenzo De Silvestri · \\ Lucia Agnoletto $\cdot$ Stefano Dolci
}

Received: 18 November 2008/Accepted: 25 May 2009/Published online: 11 June 2009

(C) The Author(s) 2009. This article is published with open access at Springerlink.com

\begin{abstract}
In the convergence slope/coastal areas of Antarctica, a large fraction of snow is continuously eroded and exported by wind to the atmosphere and into the ocean. Snow transport observations from instruments and satellite images were acquired at the wind convergence zone of Terra Nova Bay (East Antarctica) throughout 2006 and 2007. Snow transport features are well-distinguished in satellite images and can extend vertically up to $200 \mathrm{~m}$ as first-order quantitatively estimated by driftometer sensor FlowCapt ${ }^{\mathrm{TM}}$. Maximum snow transportation occurs in the fall and winter seasons. Snow transportation (drift/blowing) was recorded for $\sim 80 \%$ of the time, and $20 \%$ of time recorded, the flux is $>10^{-2} \mathrm{~kg} \mathrm{~m}^{-2} \mathrm{~s}^{-1}$ with particle density increasing with
\end{abstract}

C. Scarchilli · M. Frezzotti $(\bowtie)$ - P. Grigioni · L. De Silvestri ·

L. Agnoletto

ENEA, Rome, Italy

e-mail: massimo.frezzotti@enea.it

C. Scarchilli

e-mail: claudio.scarchilli@enea.it

P. Grigioni

e-mail: paolo.grigioni@enea.it

L. De Silvestri

e-mail: lorenzo.desilvestri@enea.it

L. Agnoletto

e-mail: lucia.agnoletto@enea.it

C. Scarchilli · L. Agnoletto

Dipartimento di Scienze della Terra, Università di Siena,

Siena, Italy

S. Dolci

CNR, Rome, Italy

e-mail: stefano.dolci@cnr.it

S. Dolci

Consorzio P.N.R.A. S.C.r.l., Rome, Italy height. Cumulative snow transportation is $\sim 4$ orders of magnitude higher than snow precipitation at the site. An increase in wind speed and transportation $(\sim 30 \%)$ was observed in 2007, which is in agreement with a reduction in observed snow accumulation. Extensive presence of ablation surface (blue ice and wind crust) upwind and downwind of the measurement site suggest that the combine processes of blowing snow sublimation and snow transport remove up to $50 \%$ of the precipitation in the coastal and slope convergence area. These phenomena represent a major negative effect on the snow accumulation, and they are not sufficiently taken into account in studies of surface mass balance. The observed wind-driven ablation explains the inconsistency between atmospheric model precipitation and measured snow accumulation value.

Keywords Surface mass balance $\cdot$ Blowing snow . Climate impact . Snow transport - Katabatic wind . East Antarctica

\section{Introduction}

Since the first expedition of Scott, Priestley, and Mawson, the slope and coastal areas of the East Antarctic Ice Sheet are known as the area of our planet with the highest winds and blowing snow. Nowhere else on Earth does a single meteorological element (wind) has such an overwhelming influence on the climate of an entire continent (Wendler et al. 1993). Strong katabatic winds blow throughout the year, and a large but unknown fraction of the snow that falls on the ice sheet is continuously exported to the atmosphere and the Southern Ocean. These processes constitute a significant negative term in the surface mass balance (SMB). SMB is given by (Déry and Yau 2002): 
Fig. 1 Satellite image in false colour (MODIS Terra, 9 November 2004) of the Terra Nova Bay area showing automatic weather station (AWS) locations, blue ice area (dark blue) and wind crust area (light blue). Contour lines every $250 \mathrm{~m}$ and snow accumulation survey site are indicated. Nansen Ice Sheet (NIS), Mario Zucchelli Station $(M Z S)$, Midpoint $(M d P t)$

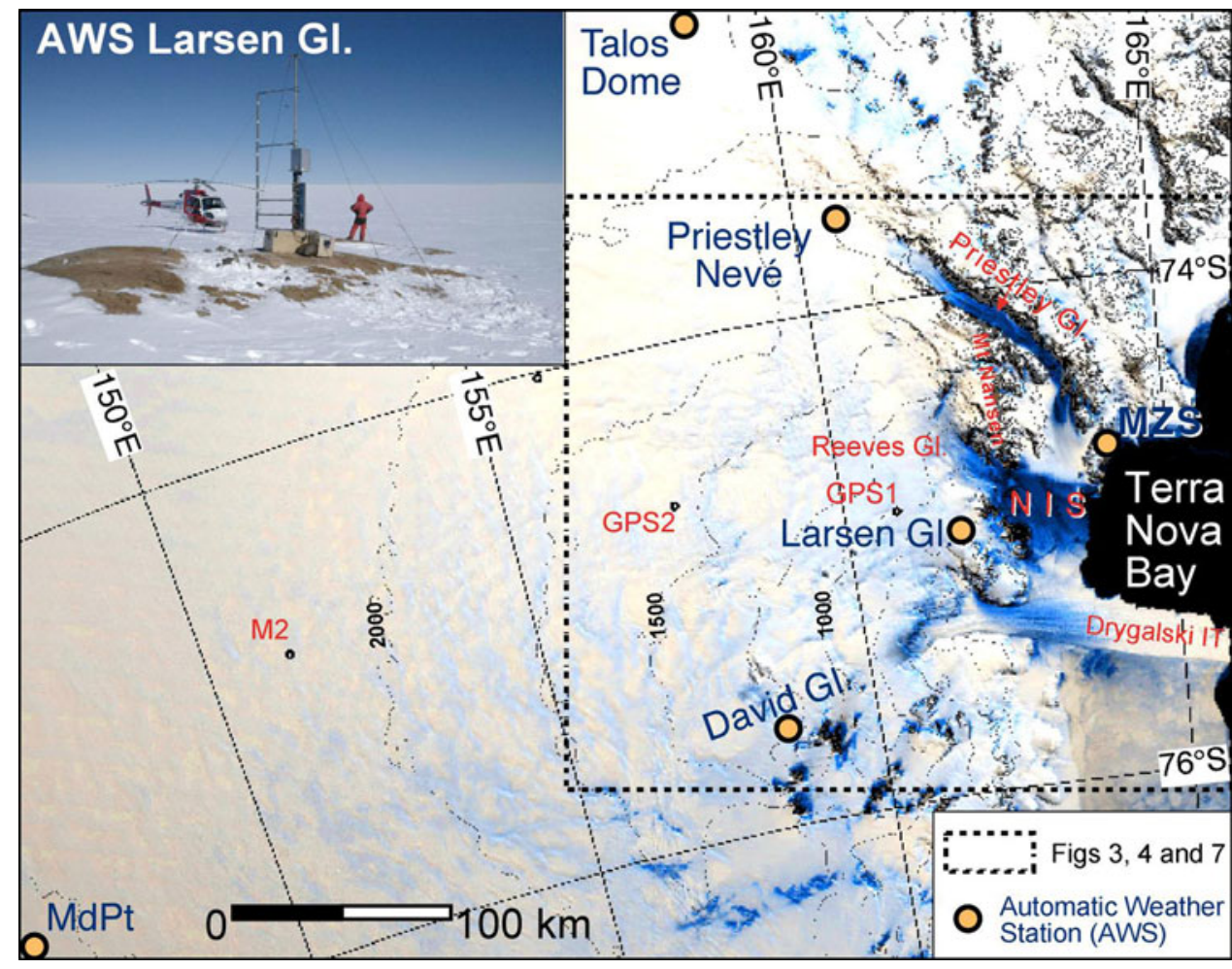

$S M B=P-E-Q_{M}-Q_{S}-\nabla Q_{T}$

where SMB indicates the surface mass balance, $P$ denotes precipitation (snowfall), $E$ is evaporation (surface sublimation), $Q_{M}$ represents snowmelt, $Q_{S}$ is the blowing snow sublimation, $Q_{T}$ is the snow transport and $\nabla Q_{T}$ is the divergence of snow transport.

The extreme environmental conditions and remote location of Antarctica have long inhibited the systematic study of its climate and snow accumulation processes. Measurement of blowing snow in Antarctica is very difficult and limited, and data are only available for a few sites (e.g., Mann et al. 2000; Nishimura and Nemoto 2005). Atmospheric models estimate that the horizontal divergence of snow by wind transport is of minor significance for integrated ice sheet SMB because the model simulations assume that katabatic winds tend to remove mass from the interior regions of the continent and displace it to coastal/convergence areas (Déry and Yau 2002; van den Broeke et al. 2006). Moreover, the blowing snow process and direct export into the ocean are not explicitly included in numerical weather forecasting and general circulation models (Gallée et al. 2001; Genthon and Krinner 2001; Krinner et al. 2007; van den Broeke et al. 2006).

On the contrary, analysis of satellite images and field observations show that the wind crust and blue ice areas (Fig. 1), characterised by SMB from nil $(-10 \mathrm{~kg}$ $\mathrm{m}^{-2}$ year $^{-1}<$ wind crust $\leq 10 \mathrm{~kg} \mathrm{~m}^{-2}$ year $^{-1}$ ) to strong negative $\left(-500 \mathrm{~kg} \mathrm{~m}^{-2}\right.$ year $^{-1}<$ blue ice area $\leq-$
$10 \mathrm{~kg} \mathrm{~m}^{-2}$ year $^{-1}$ ), are very well-distributed on the katabatic wind convergence area and the coastal/slope area, representing more than $50 \%$ of the surface of the slope and coastal area within $300 \mathrm{~km}$ of Terra Nova Bay (Frezzotti et al. 2002b, 2004). Snow accumulation surveys show that ablation by wind-driven processes represent from $20 \%$ to more than $80 \%$ of the solid precipitation, and that depositional processes are very rare and negligible in the SMB (Frezzotti et al. 2004, 2007). Gallée et al. (2005) compared snow accumulation measurements and model outputs for the same time periods, the model is found to simulate well the spatial and temporal variability of the SMB when take in account wind erosion.

In this study, field measurements are integrated with satellite image analysis to make the first-order quantitative estimation of blown snow exported to the atmosphere and ocean in a slope/coastal katabatic wind convergence area, the Terra Nova Bay (East Antarctica).

\section{Site characteristics and instruments}

The Larsen Glacier (Fig. 1; $74^{\circ} 57^{\prime} \mathrm{S}, 161^{\circ} 46^{\prime} \mathrm{E}$; about $1,350 \mathrm{~m}$ above sea level in altitude) is located between the Reeves and David Glaciers, about $50 \mathrm{~km}$ inland from Terra Nova Bay (Northern Victoria Land, East Antarctica). Katabatic winds that frequently exceed $25 \mathrm{~m} \mathrm{~s}^{-1}$ blow from the south and converge along the David, Reeves, and Priestley valleys in Terra Nova Bay, deflecting from the S-N to W-E and NW-SE directions (Bromwich et al. 1990). 
The site is at the limit of the Antarctic plateau before an orographic jump of more than 1,200 m over less than $20 \mathrm{~km}$ from the plateau to the coast. Another instrument was installed at midpoint $(\mathrm{MdPt})$, a plateau site about $600 \mathrm{~km}$ from the coast (Fig. 1: $75^{\circ} 32^{\prime} \mathrm{S}, 145^{\circ} 51^{\prime} \mathrm{E} ; 2,510 \mathrm{~m}$ above sea level in altitude).

A snow transport instrument and an automatic weather station (AWS) were installed in early January 2006 and in January 2007, respectively, on rock outcrops in the upper part of Larsen Glacier (Fig. 1). Snowdrift measurements were carried out using a driftometer sensor FlowCapt ${ }^{\mathrm{TM}}$ of IAV Acoustics and Vibration Engineering (Chritin et al. 1999), which is able to survey extended snow transportation events in a remote area under harsh conditions (Jaedicke 2001). Snow drift/blowing impact induces a measurable acoustic vibration in the sensor body. The instrument can supply mass flux rate assuming that the particles all have the same elastic characteristics and the impact depends on particle momentum. Using frequency filtering, the sensor precisely discriminates the low frequency wind effect from the high frequency snowdrift signal. The instrument is calibrated by the manufacturer and offers reproducibility in the $\pm 5 \%$ range at the nominal single working point (Chritin, IAV Engineering, personal communication). However, the real accuracy of a FlowCapt flux measurement is an open question among the scientific community (Cierco et al. 2007). The instrument seems to underestimate flux in cold conditions (temperature $<-5^{\circ} \mathrm{C}$ ) with low-density snow flux and overestimate during warm and high snow density conditions (Lehning et al. 2002). Moreover, Cierco et al. (2004, 2007) have argued the instrument needs to be improved because the snow grain type and particle velocity play significant roles in flux rate estimation. Nevertheless, the extreme temperature condition registered for the Larsen site (never above $-10^{\circ} \mathrm{C}$, even during the austral summer) allows us to consider the measured fluxes as a lower limit of the real snow transportation.

The Larsen snow transportation instrument has four sensor segments, each of which is $1 \mathrm{~m}$ length and samples at nominal heights of $0.7,1.7,2.7$, and $3.7 \mathrm{~m}$, respectively. It measures hourly snow transport flux (FC) data $\left(\mathrm{kg} \mathrm{m}^{-2} \mathrm{~s}^{-1}\right)$, the datalogger internal temperature $\left({ }^{\circ} \mathrm{C}\right)$, and an index proportional to the hourly maximum wind speed $\left(\mathrm{m} \mathrm{s}^{-1}\right)$. Unfortunately, the AWS (wind speed and direction, temperature, humidity) did not collect any data due to a problem with the datalogger battery.

The FC measurements were averaged over $6 \mathrm{~h}$ and transformed into discrete values of $\eta$ (snowdrift density in $\mathrm{kg} \mathrm{m}^{-3}$ ) by dividing the $u$ (wind speed average) calculated at measurement levels, assuming a neutral profile of surface layer (Bintanja 1998; Mann et al. 2000). This assumption does not accurately represent the actual Antarctic surface layer, especially during snowdrift conditions
(Bintanja 2001). However, field snowdrift experiments in Antarctica (Mann 1998; Bintanja and Reijmer 2001) find little or no deviation from a logarithmic fit in snowdrift conditions. The $\eta(z)$ continuous profiles are evaluated by fitting the $\eta$ discrete values to the power law for steady state conditions (Shiotanai and Arai 1967):

$\frac{\eta(z)}{\eta\left(z_{r}\right)}=\left(\frac{z}{z_{r}}\right)^{-\frac{w_{f}^{\text {averaged }}}{k u *}}$,

where $\eta\left(z_{r}\right)$ is the density at a reference height $z_{r}$, $u_{*}$ the friction velocity and $w_{f}^{\text {averaged }}$ is the mean falling velocity of a snow particle. It is considered as independent of particle size (Mann et al. 2000) and it is calculated as the second parameter in the previous fitting. The $w_{f}^{\text {averaged }}$ and $u_{*}$ are considered independent of height (Bintanja 1998). The transport rate $Q_{T}\left(\mathrm{~kg} \mathrm{~m}^{-1} \mathrm{~s}^{-1}\right)$, is calculated as:

$Q_{T}=\int_{z_{\text {salt }}}^{z_{\text {top }}} \eta(z) u(z) \mathrm{d} z$,

where $z_{\text {salt }}, z_{\text {top }}, \eta\left(z_{r}\right)$ and $u(z)$ are the height of the saltation layer, the maximum height of suspension layer, the density, and wind profiles' height, respectively. The $z_{\text {salt }}$ and $z_{\text {top }}$ are considered constant, and are held equal to 0.1 and $12 \mathrm{~m}$, respectively.

Standard similarity theory ceased to be valid during strong events because the constancy assumption for turbulent fluxes above the surface is inaccurate (Bintanja 1998) and the power law does not fit the data. During those cases, the density is considered constant over the sensor length and $Q_{T}$ is calculated by simply summing the measured fluxes.

In lieu of the experimental data not recorded by the AWS, wind velocity $(u)$ at Larsen is evaluated from the European Centre for Medium-Range Weather Forecasts (ECMWF) operational analysis, taking the nearest of the four ECMWF grid points as the best representation of wind speed at our site. Wind velocity at synoptic hours $(0 / 6 / 12 / 18$ UTC) is used as the reference wind speed in the calculation of snow transport. Cullather et al. (1997) evaluate the ECMWF operational analysis, finding that it shows general agreement with the available radiosonde. Agnoletto (2009) have examined surface winds from the ECMWF forecast and compared them with available data from an AWS of Terra Nova Bay area and conclude that wind speeds are simulated with "reasonable accuracy". Grid data with a spatial resolution of $1.125^{\circ} \times 1.125^{\circ}$ is used in this analysis. This is not the highest spatial resolution for ECMWF analysis available during the studied period, but correlation analysis with experimental measurements shows that it is closer to observational data with respect to the finest spatial grid product. Wind velocities, measured hourly by AWS (www.climantartide.it) at Priestley Nevé (Fig. 1; about 
$150 \mathrm{~km} \mathrm{NW}$ of Larsen Site, $73^{\circ} 38^{\prime} \mathrm{S} ; 160^{\circ} 38^{\prime} \mathrm{E}$ ) and at David Glacier (About $115 \mathrm{~km} \mathrm{~S}$ of Larsen site, $75^{\circ} 36^{\prime} \mathrm{S}$; $158^{\circ} 35^{\prime} \mathrm{E}$ ), are sampled at synoptic hours and compared with their nearest ECMWF grid data point for $1.125^{\circ} \times 1.125^{\circ}$ and $0.3^{\circ} \times 0.3^{\circ}$ grid resolution data product (Fig. 2). Conversely, the near-surface model wind field follows the trend of the measured data, even if it shows a smoothed representation of observation. Greater differences in measurements can be due to model difficulties in properly estimating high speeds during katabatic conditions. Higher correlations are found between the $1.125^{\circ} \times 1.125^{\circ}$ grid and both AWSs $(R=0.76$ David Glacier and 0.51 Priestley Nevé), with root mean square errors (RMS) of 4.13 and $2.87 \mathrm{~m} \mathrm{~s}^{-1}$. A comparison between $0.3^{\circ} \times 0.3^{\circ}$ grid and AWS shows a good correlation with AWS at David Glacier $(R=0.83, \mathrm{RMS}=4.43)$, but a larger discrepancy at Priestley Nevé $(R=0.26, \mathrm{RMS}=5.2)$. This is probably due to the AWS position at the gate of Priestley Glacier (a canyon approximately $5 \mathrm{~km}$ wide), and this feature is not sufficiently resolved over a $0.3^{\circ} \times 0.3^{\circ}$ grid. Because of the limited resolution, the $0.3^{\circ} \times 0.3^{\circ}$ grid is not able to appropriately reproduce the local wind at site, whereas the $1.125^{\circ} \times 1.125^{\circ}$ grid, smoothing the local incorrect wind with an interpolation over more points, can be considered an average value over a regional area and adequately represents the main wind signal (Fig. 2).

Precipitation $(P)$ and evaporation $(E)$ are evaluated from ECMWF +24 h operational forecasts because $P$ and $E$ are not analysed but only predicted in ECMWF. The forecast temporal resolution is chosen to avoid errors associated with the spin-up model that arise from the adjustment of the simulated atmosphere that are performed to ensure consistency with the physics at model initialization (Genthon et al.
2003). Snow transport divergence, and surface and blowing snow sublimation are calculated using the same approach of Déry and Yau (2002), initialized with zonal, meridional surface wind, temperature and dewpoint temperature at $2 \mathrm{~m}$ from the ECMWF operational analysis data. Snowmelt is a negligible phenomenon in the Terra Nova Bay area (annual temperature mean at sea level $-15^{\circ} \mathrm{C}$ ).

The lifetime of a blown snow particle is calculated using the basic formula for the change in mass of a spherical ice particle in an environment with a water vapour deficit, as described in Taylor et al. (2006). This approach has been widely used in other studies of blowing snow in Antarctic environments (Déry et al. 1998; Mann et al. 2000).

Katabatic flow and blowing snow can be observed at the regional scale using satellite imagery (e.g., Déry and Yau 2001). We observed and analysed these phenomena using daily MODIS TERRA and AQUA satellite images in truecolour along with infrared images with a pixel size of $250 \mathrm{~m}$ (http://rapidfire.sci.gsfc.nasa.gov/subsets/) from August 2005 to October 2008. Snow transport features (billows and atmospheric dunes) are very well-recognised on satellite images, distinguished by cumulus clouds (whether in a random cloud field or in organised cloud streets) that would otherwise exhibit a more cellular appearance (Fig. 3). Snow transport features are thick enough and possess enough vertical extent to cast shadows, especially during times of low sun angle (spring and fall). These particular shadows stand out even more since they are against a white (snow pack) background. Satellite images were classified into categories of no "billow", lightly developed "billow", heavily developed "billow", and clouds. Billow features are always associated with the mouth of the Terra Nova Bay polynya due to katabatic
Fig. 2 Surface wind speed time series measured at AWS (grey line) and obtained from ECMWF operational analysis at $1.125^{\circ} \times 1.125^{\circ}$ (black line) and $0.3^{\circ} \times 0.3^{\circ}$ (blue line $)$ of grid resolution for David Glacier (upper panel) and Priestley Nevé (lower panel) sites from January 2006 to January 2008

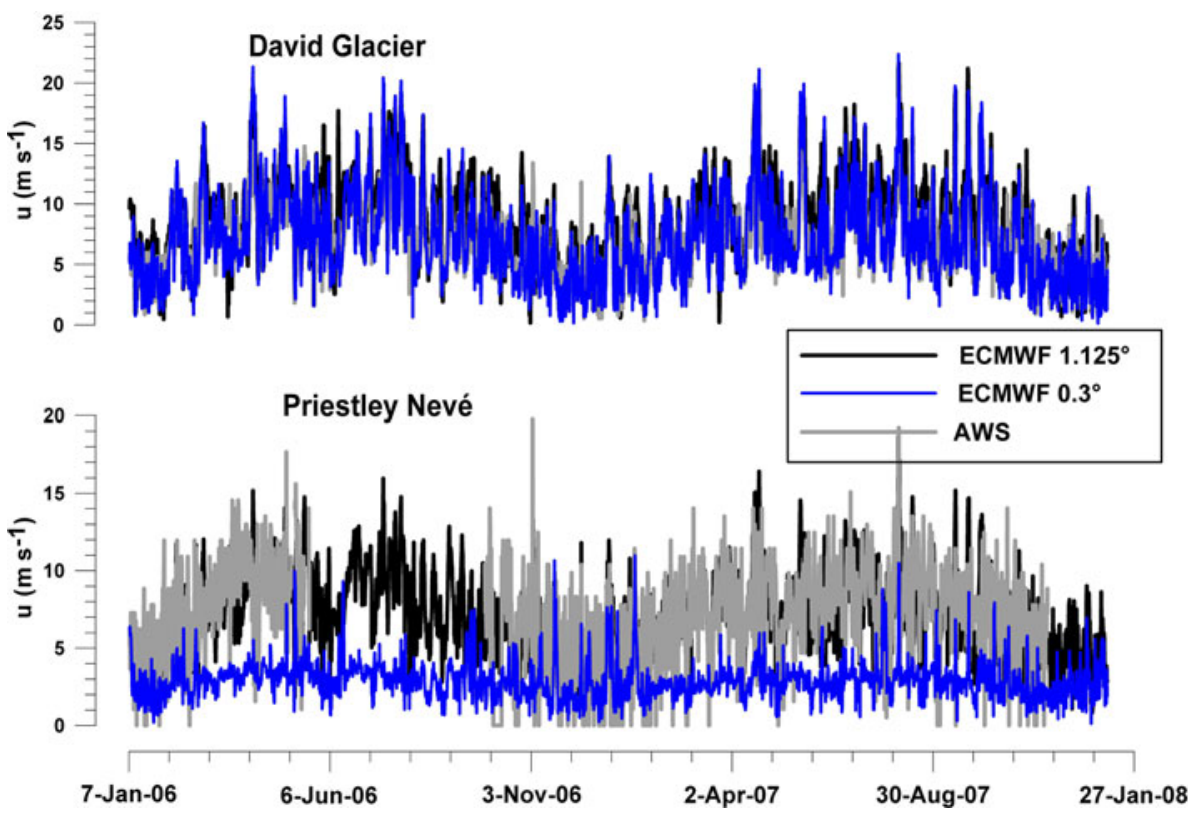


winds, with clear sea ice drift from the Nansen Ice Sheet front to the east. Due to an absence of illumination at $75^{\circ} \mathrm{S}$ during the Antarctic winter, satellite images are only available from mid August to the end of April.

\section{Results}

Snow transportation by saltation (within $0.3 \mathrm{~m}$ in elevation) starts at wind speeds between 2 and $5 \mathrm{~m} \mathrm{~s}^{-1}$, transportation by suspension (drift snow) starts at velocities greater than $5 \mathrm{~m} \mathrm{~s}^{-1}$ (within $2 \mathrm{~m}$ ), and blowing snow (snow transportation higher than $2 \mathrm{~m}$ ) starts at velocities between 7 and $11 \mathrm{~m} \mathrm{~s}^{-1}$ (see Frezzotti et al. 2004 and references therein). The threshold wind speed at which the sublimation of blowing snow starts to contribute substantially to katabatic flows in a feedback mechanism appears to be $11 \mathrm{~m} \mathrm{~s}^{-1}$ (Kodama et al. 1985; Wendler et al. 1993). An increase in drifting snow leads to an increase in air density due to cooling from drifting snow sublimation and to particle incorporation, thus increasing katabatic flow speeds by another 20-30\% (Kodama et al. 1985). AWS and wind morphology (Frezzotti et al. 2002a) along the transect from Terra Nova Bay to Dome C show that within $600 \mathrm{~km}$ from the coast, wind speed is higher than $2 \mathrm{~m} \mathrm{~s}^{-1}$ for $90 \%$ of the time (drift snow), higher than $5 \mathrm{~m} \mathrm{~s}^{-1} 65-80 \%$ of the time (blowing snow), and wind speeds higher than $11 \mathrm{~m} \mathrm{~s}^{-1}$ occur $15-40 \%$ of the time.

The survey macroscale features formed by intense snow transportation and extension were determined by satellite image analysis (Figs. 3, 4). Ground truthing by direct field observation (during summer season by field, helicopter and aircraft; see also Zibordi and Frezzotti 1996) and using FlowCapt instruments (Fig. 4) have confirmed the true nature of the extensive blowing snow phenomen observed on satellite images. Snow transportation fluxes can be recognised as straight swaths, more or less marked upward along the wind direction with respect to the terrain. The blowing snow phenomenon has the typical texture of elongated feature "billows", with wave-like that lie
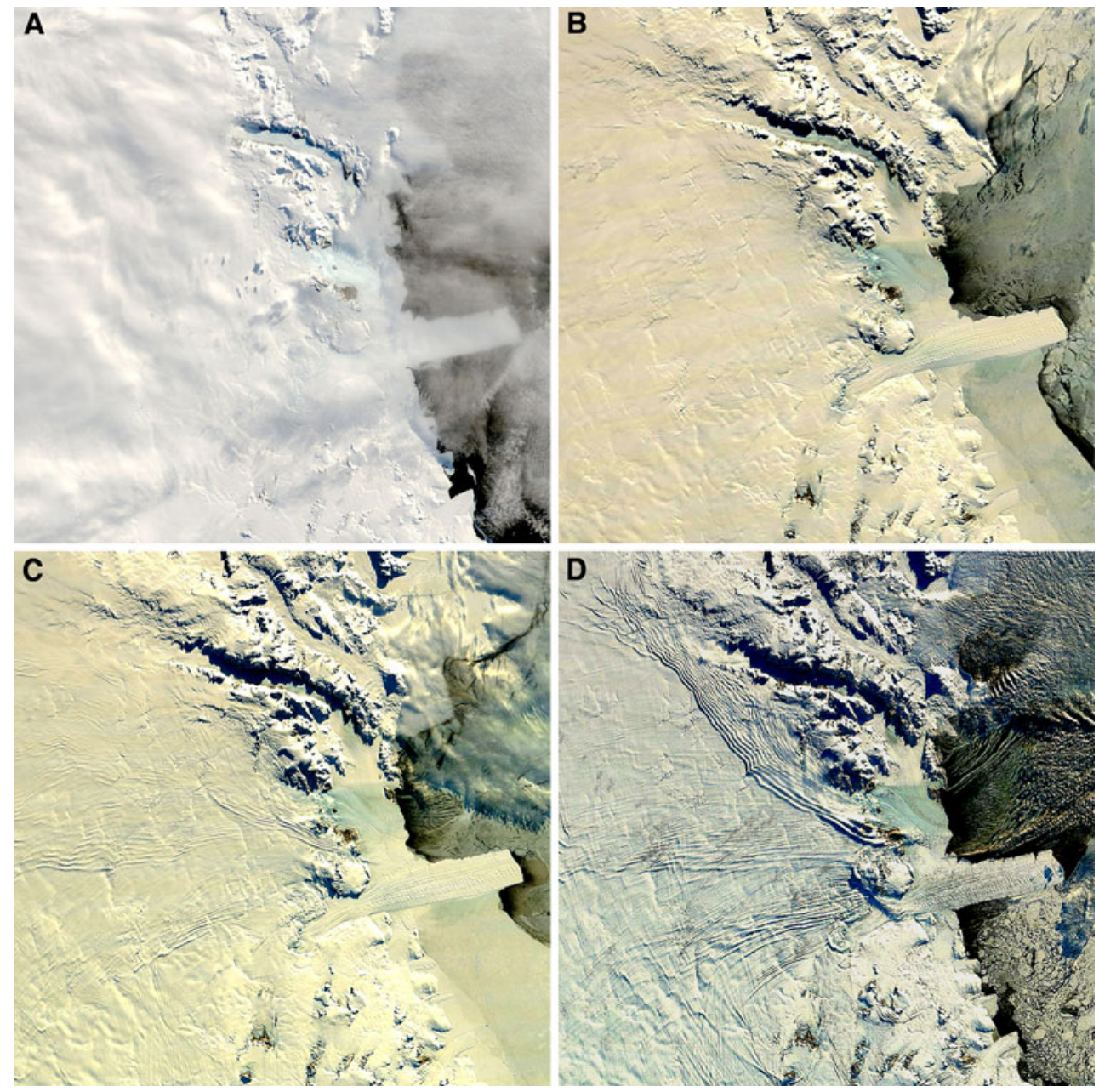

Fig. 3 True colour MODIS TERRA images of Terra Nova Bay area during: a clouds (26 May 2007; 21:20 UTC); b no drift (28 September 2008; 22:30 UTC), c light billows (16 September 2008; 22:05 UTC); d heavy billows (26 March 2007; 21:45 UTC) 
Fig. 4 True colour MODIS TERRA images for light (a 12 October 2006, 22:20 UTC) and heavy (b 25 September 2007; 21:05 UTC) snow transportation; panels show measured snow transport fluxes measured simultaneously with satellite image acquisition. Black dot is position of Larsen AWS
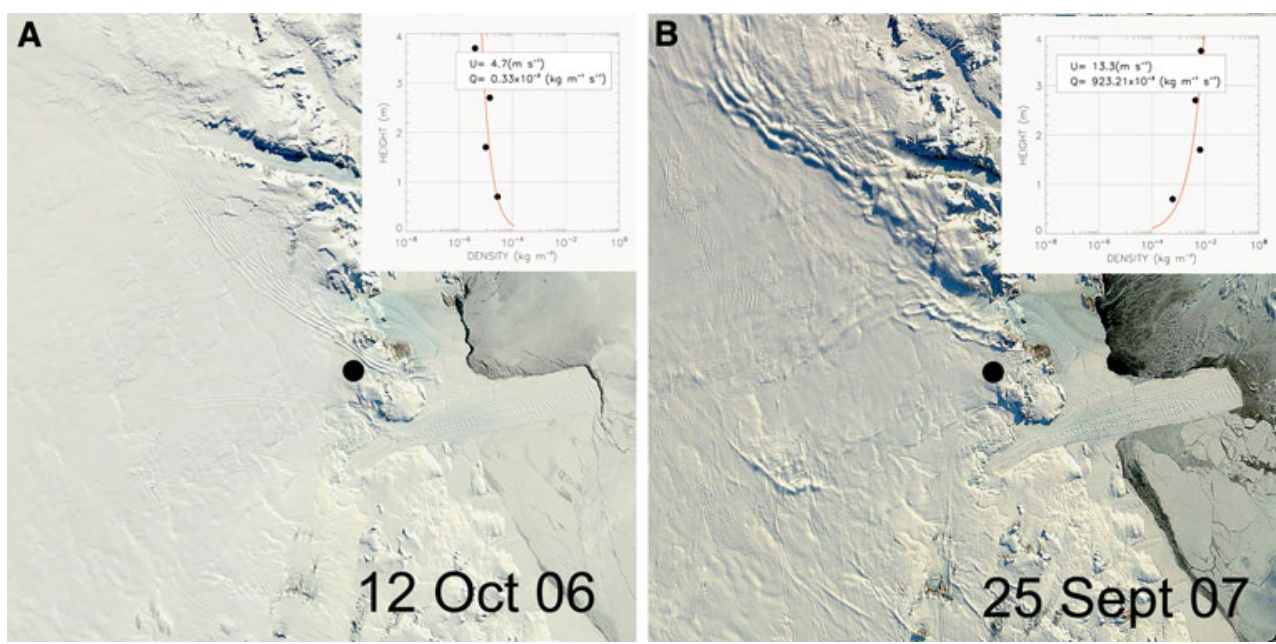

perpendicular to the wind direction and the similar "atmospheric dune". Turbulent billow features were aligned parallel to the surface winds, focusing blown snow into airborne "billows" and "atmospheric dunes" that were dense enough and high enough to cast shadows.

Analysis from August 2005 to October 2008 clearly shows the minimum observation of "billows" over the summer period (from mid-November to January), while this phenomenon occurs more than $90 \%$ of the time during the spring and fall months with maximum values in April and September (no image is available from May until August).
Instruments show that snow transportation (drift/blowing) is a common feature of the Larsen site. Analysis of 6 h-averaged flux profiles for 2006-2007 show a high degree of variability, with values from $1 \times 10^{-6}$ to $4 \times 10^{-1} \mathrm{~kg} \mathrm{~m}^{-2} \mathrm{~s}^{-1}$ recorded over all four sensors (Fig. 5). About $20 \%$ of the time, none of the sensors measured the impact of snow (the lowest limit sensor goes up to $20 \mathrm{~cm}$ ), and thus the saltation phenomenon was not surveyed, whereas in $\sim 80 \%$ of the cases, snow transportation (drift/blowing) was recorded. In most cases, snow transportation was well developed for several metres above
Fig. 5 Snow transport parameters at the Larsen site for the period 2006-2008. Lower panel ECMWF wind speed time series $\left(\mathrm{m} \mathrm{s}^{-1}\right.$, orange line), $+24 \mathrm{~h}$ forecasted ECMWF precipitation $\left(\mathrm{kg} \mathrm{m}^{-2}\right.$, black line) and 0-12 $\mathrm{m}$ integrated snow transport $\left(10^{3} \mathrm{~kg} \mathrm{~m}^{-1}\right.$, blue line). Upper panel cumulative value of $+24 \mathrm{~h}$ forecasted ECMWF precipitation (black line), cumulative value of $+24 \mathrm{~h}$ forecasted ECMWF surface sublimation (orange line), cumulative value of blowing snow sublimation (red line), and cumulative value of $0-12 \mathrm{~m}$ integrated snow transport (blue line)

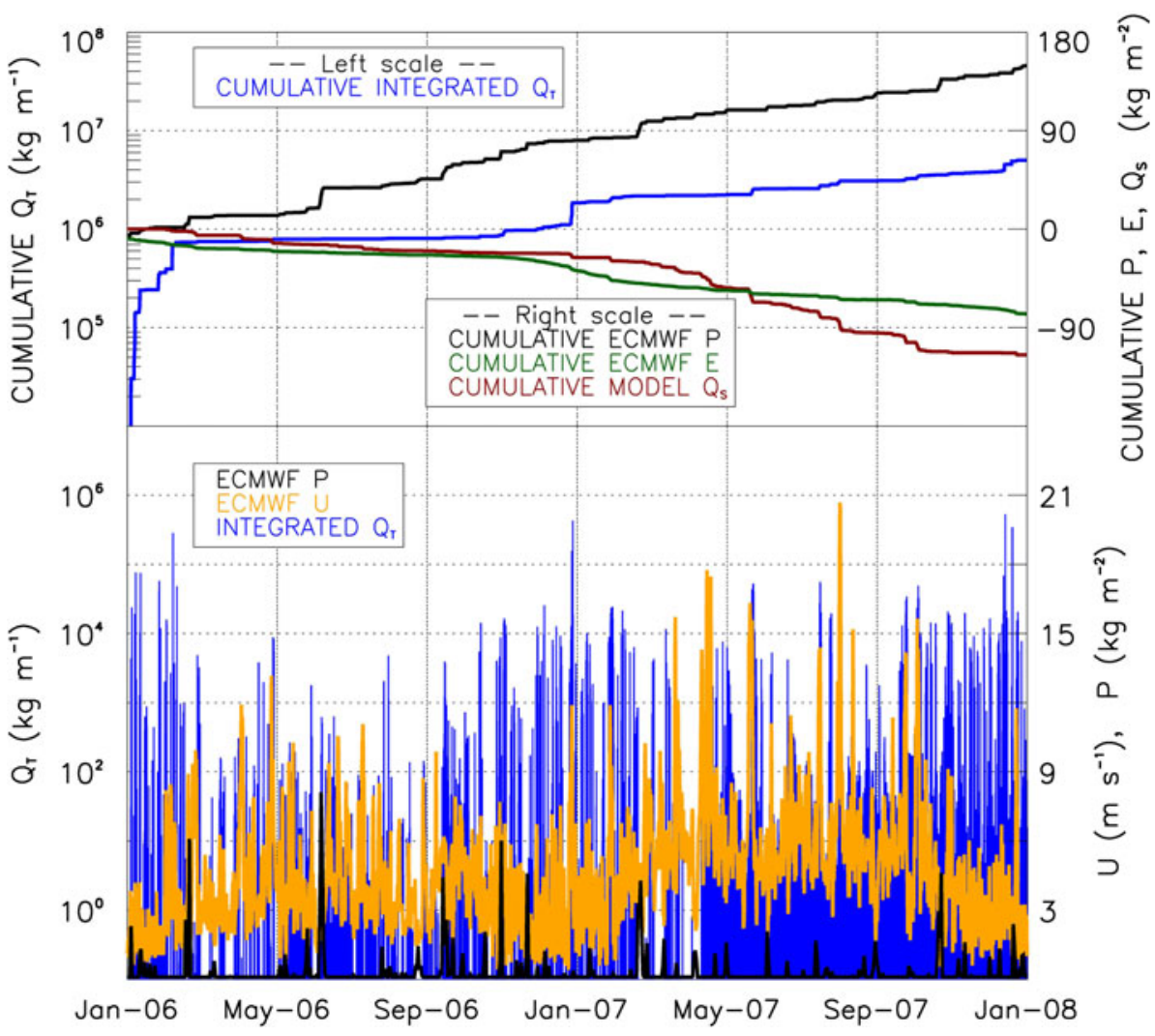


the surface, with snow impact signals registered simultaneously by the four sensors. In $\sim 60 \%$ of cases, snow transport occurs when $u$ ranges from 2 to $8 \mathrm{~m} \mathrm{~s}^{-1}$ and cumulative mean flux over the height is low $\left(<1 \times 10^{-2} \mathrm{~kg} \mathrm{~m}^{-2} \mathrm{~s}^{-1}\right)$. Snow transport follows the classic negative power law (Mann et al. 2000) with a decrease in particle radius with height. Thus, only lighter particles are probably able to blow to upper layers $(>4 \mathrm{~m})$. In the residual $20 \%$ of snow transportation cases, no power law can approximate the profiles: particle density increases with height, mean cumulated flux can assume high values $\left(>1 \times 10^{-2} \mathrm{~kg} \mathrm{~m}^{-2} \mathrm{~s}^{-1}\right)$, and $u$ occasionally (10\% of the time) goes up to $10 \mathrm{~m} \mathrm{~s}^{-1}$.

The calculation of transport rate $\left(Q_{T}\right)$ integrated over $12 \mathrm{~m}$ in height gives the value of $5 \times 10^{6} \mathrm{~kg} \mathrm{~m}^{-1}$ summed over the entire campaign period, and $55 \%$ of the mass is transported in drift conditions (within $2 \mathrm{~m}$ ). About $3 \times 10^{6} \mathrm{~kg} \mathrm{~m}^{-1}$ is carried at times when the density decreases with height from the surface, whereas some less typical transport occurs when the density increases with height. Measurements of snow transportation at the MidPoint site show a value of $0.1 \times 10^{6} \mathrm{~kg} \mathrm{~m}^{-1}$ for 7 months of measurements, between December 2005 and November 2006. Due to low temperatures, the instrument did not record transportation from April to August 2006.

The $Q_{T}$ is determined by a complex interaction between surface conditions and turbulent flow. A number of transport rate field studies have been performed in different parts of the world: at the Halley site (Antarctica) during the British Antarctic Survey's second stable Antarctic boundary layer experiment (Mann et al. 2000); at the Byrd station, Antarctica (Budd 1966); at the Mizuho station, Antarctica (Takahashi 1985; Nishimura and Nemoto 2005); at Laramie, Wyoming (Schmidt 1982); and the Canadian Prairies (Pomeroy 1988). It is very difficult to generalise drift processes or compare results obtained in different sites. However, it can be noted that a value of $5.2 \times 10^{5} \mathrm{~kg} \mathrm{~m}^{-1}$ for $Q_{T}$ during December, January, and February 2007 obtained for Larsen is very close to the $5.5 \times 10^{5} \mathrm{~kg} \mathrm{~m}^{-1}$ for the same months in 1991 at the Halley site, presented by Mann et al. (2000). More general comparisons between parameterisations presented in the literature and measurements at the Larsen site highlight a good agreement for small transport rates, in particular for the Takahashi (1985) formula. But, they also show a trend of underestimating higher transport rates. Comparisons of our $Q_{T}$ instrumental measurements and atmospheric models show a value one order of magnitude greater than Déry and Yau (2002), and similar value to that estimated by van den Broeke et al. (2006). The dissimilar estimation by Déry and Yau (2002) is probably caused by differences in the model data used to initialize the calculation (ERA15 respect to RAMCO 2/ANT) and parameterisations.
Sublimation processes $\left(Q_{S} 57 \mathrm{~kg} \mathrm{~m}^{-2}\right.$ year $^{-1} ; \quad E$ $34 \mathrm{~kg} \mathrm{~m}^{-2}$ year $^{-1}$ ) remove $91 \mathrm{~kg} \mathrm{~m}^{-2}$ year $^{-1}$ at the Larsen site (Fig. 5) and $17 \mathrm{~kg} \mathrm{~m}^{-2}$ year $^{-1}$ at the MidPoint site $\left(Q_{S} 14 \mathrm{~kg} \mathrm{~m}^{-2}\right.$ year $\left.^{-1} ; E 3 \mathrm{~kg} \mathrm{~m}^{-2} \mathrm{yr}^{-1}\right)$. Estimation of sublimation processes agrees well with the results proposed by another SMB study (van den Broeke et al. 2006; Déry and Yau 2002). The majority of snowfall $(P)$ events occur when $u$ is less than $8 \mathrm{~m} \mathrm{~s}^{-1}$, but no particular dependence on $P$ intensity is apparent with wind speed. A wind increase is clear in 2007, especially during the fall and winter seasons when the mean $u$ value is $\sim 6.5 \mathrm{~m} \mathrm{~s}^{-1}$, which is $\sim 2.5 \mathrm{~m} \mathrm{~s}^{-1}$ higher than the mean velocity for the same periods in 2006. No correlation has been found in the ECMWF data between snow transportation phenomena and snowfall.

\section{Discussion}

Snow accumulation at Terra Nova Bay is about 150 $200 \mathrm{~kg} \mathrm{~m}^{-2}$ year $^{-1}$ (Stenni et al. 2000; Frezzotti et al. 2004) in a relatively undisturbed wind area. The Larsen site $Q_{T}\left(2.5 \times 10^{6} \mathrm{~kg} \mathrm{~m}^{-1}\right.$ year $\left.^{-1}\right)$, integrated over a $12 \mathrm{~m}$ height, is about four orders of magnitude greater than the annual snow accumulation. At the MidPoint site, $Q_{T}$ is about $0.05 \times 10^{6} \mathrm{~kg} \mathrm{~m}^{-1}$ year $^{-1}$, three orders of magnitude greater than the snow accumulation (40$60 \mathrm{~kg} \mathrm{~m}^{-2}$ year $^{-1}$ ). The calculation is affected by significant uncertainties, but most calculations represent the lower limit and can result in underestimation. Examples of such underestimations are: the underestimation of flux by FlowCapt ${ }^{\mathrm{TM}}$ driftometer in cold conditions, the complete lack of recognition of suspended particle distribution at heights of over $4 \mathrm{~m}$ (about $20 \%$ of events), a phenomenon that contributes to snow transport in some cases, and also the underestimation of $u$ using model data. The blue ice area of the Nansen Ice Sheet occurs downwind of the Larsen site, therefore the blowing snow that transits at this site is completely sublimated in the atmosphere (mainly) or exported directly to the polynya.

During heavy billow events, the height of transport fluxes can be estimated at up to a $200 \mathrm{~m}$ through, as shown by a comparative analysis between shadows produced by the Larsen Glacier walls and those projected by the billows' turbulent features. Incorporating the known sun elevation at the image time survey and the length of the shadows on the satellite image, we were able to calculate the elevation of the billows and atmospheric dunes. The snow transportation thickness is comparable with lidar measurements at the South Pole as published by Mahesh et al. (2003), who proposed a mean blowing snow layer of up to $400 \mathrm{~m}$, with approximately $50 \%$ of the layer less than $200 \mathrm{~m}$ in thickness. Other authors (e.g., Budd et al. 1966; 
Wendler et al. 1993) report, based on visual observation, that the plumes of suspended blowing snow can reach heights of hundreds of metres, and that a snow load of $10^{-2} \mathrm{~kg} \mathrm{~m}^{-3}$ is not rare with heavy winds (Loewe 1974). Satellite images show that billow features sometimes disappear just before reaching the Larsen site due to sublimation of flux. Comparisons between snow transport evaluated by instruments and the presence of heavy billow features at the Larsen site indicate that it is probably not possible to survey some of the billow features because of the position of the site, delivering a clear underestimation of snow transportation.

For the most marked transportation cases, as selected through images (Fig. 6), the associated vertical flux measurements do not feature decreasing density with height, implying that a non-negligible quantity of snow particles is transported up to the top of the flux. Transport estimation increases up to $30 \%$ for the suspended snow flux from 4 to $50 \mathrm{~m}$, assuming a simple decreasing linear trend.

Long (tens of $\mathrm{km}$ ) and very well-developed snow transportation features are recognisable in satellite images of the plateau area, but snow billow frequently disappears from the image when there is a change in slope (Mt. Nansen, Reeves and David Glaciers ice fall). Snow billow does not appear over the Nansen Ice Sheet and Terra Nova polynya. In fact, a $200 \mathrm{~m}$ thickness of suspended snow disappears within few $\mathrm{km}$ downwind (Fig. 7). The presence of extensive blue ice (Fig. 1) occurs in this convergence region (Skinner Ridge, Nansen Ice Sheet, Drygalski Ice Tongue, Reeves and Priestley Glaciers etc.), where the 70$100 \mathrm{~m}$ thick firn layer has been removed by wind. Since ice sublimes at a rate of more than $500 \mathrm{~kg} \mathrm{~m}^{-2}$ year $^{-1}$
(Frezzotti et al. 2000), the snow precipitation (from 200 to $250 \mathrm{~kg} \mathrm{~m}^{-2}$ year $^{-1}$ ) is blowing/subliming away, with a total negative SMB of around $700 \mathrm{~kg} \mathrm{~m}^{-2}$ year $^{-1}$. These phenomena can only be explained by a sudden rapid increase in wind speed and turbulence due to the sudden slope change at the ice fall, which promotes the complete sublimation of blowing snow particles. Formation of foehn wall orographic clouds has been observed downwind of Mt. Nansen (Zibordi and Frezzotti 1996, in this study), and roll vortices have been seen east of Terra Nova Bay polynya (van Woert et al. 2001, this study).

Satellite images frequently show spectacular snow transportation phenomena with wave-like features or atmospheric dunes (with 5-10 km wavelengths) close to Mt Nansen where katabatic winds strike against the mountain slope opposite to the wind direction (Fig. 7). The position of the "atmospheric dune" is persistent between images and is well correlated to the change in slope. The relationship between the "atmospheric dune" shadow and billow shadow indicates that the "dune" forms at higher levels (tens of metres) of billow. These peculiar wave-like features look like the dune and megadune features that were recorded by snow radar survey under the ice sheet surface (Anschutz et al. 2006; Frezzotti et al. 2002a, 2007). To explain the formation of dunes and megadunes, authors hypothesised that the formation of a resonant gravityinertia wave disturbs the katabatic wind flow at the break of the slope (Pettré et al. 1986; Frezzotti et al. 2002b).

As observed at the South Pole, larger values of blown snow transport rates are not always correlated to higher wind speed (Mahesh et al. 2003). Blowing snow is correlated to snow available for transportation (Gallée et al.
Fig. 6 Cumulative monthly occurrences of no drift conditions (grey bars), light (red bars) and heavy (blue bars) snow transportation inferred from MODIS TERRA images; and cumulative monthly occurrences for no drift ( grey line), light (red line) and heavy (blue line) snow transport events inferred from the FlowCapt instrument at the Larsen site

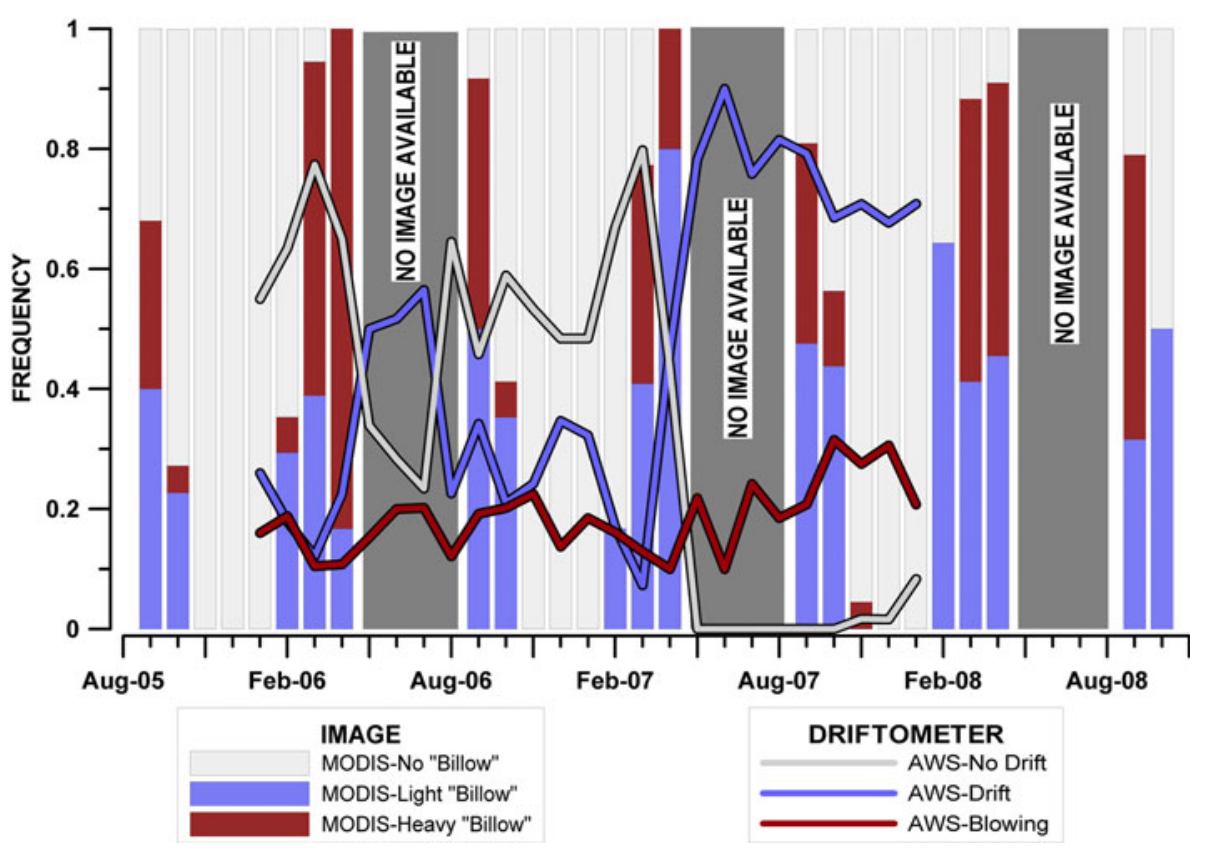




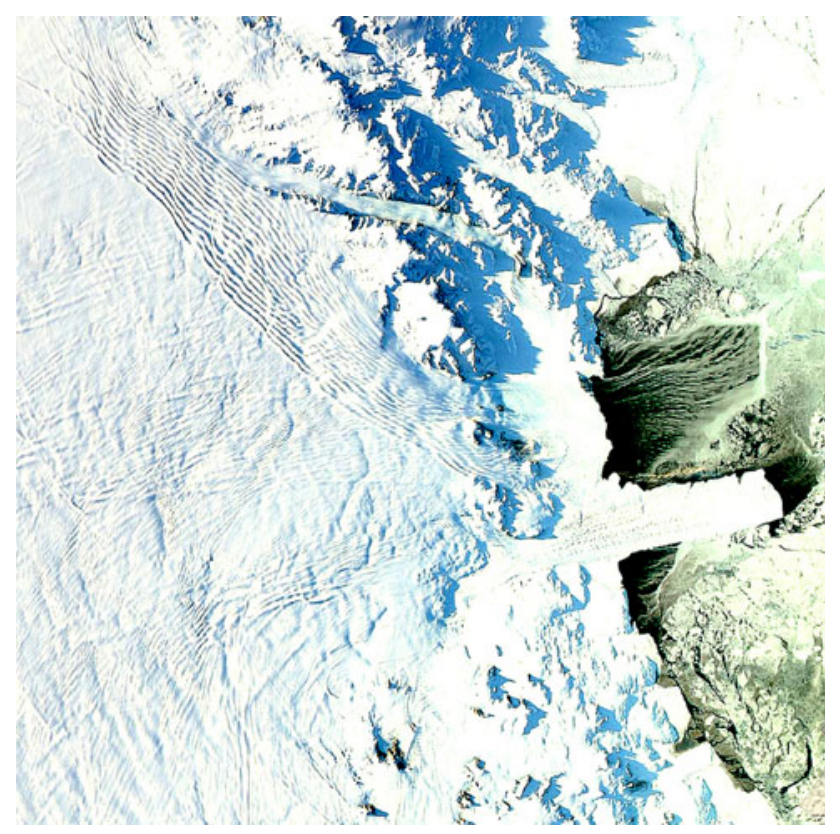

Fig. 7 Detail of Mt Nansen in a MODIS TERRA image (2 April 2008; 22:55 UTC) during a heavy billow event

2001) and to the wind speed threshold at which the sublimation of blowing snow begins contributing substantially to the katabatic flows in a feedback mechanism (Fig. 5). Stronger winds promote greater sublimation of blowing snow because air moving down the Antarctic slope is adiabatically warmed, resulting in unsaturated air (Wendler et al. 1993). This allows particles to sublime completely in strong winds, whereas in medium-strength winds they may remain saturated with respect to ice and transportation could occur (Mahesh et al. 2003). Snow radar and remote sensing surveys show that wind-driven ablation (blowing sublimation and snow transport) is strictly correlated to slope along wind direction (Frezzotti et al. 2004, 2007) and not correlated to divergence/convergence versus ablation/ deposition processes. Wind-driven ablation removed from the surface has an average value from 55 (GPS2) to 35\% (M2 and MdPt) of the precipitation, and reaches a maximum value of ablation at $85 \%$ (M2) of the precipitation (Frezzotti et al. 2004, 2005). The extensive erosion confirmed by wind crust presence on the slope convergence area and the wide presence of blue ice in the area downwind of the coastal area show that transported snow is primarily exported directly in the atmosphere (blowing sublimation) and secondarily in the ocean. Snow depositional processes are very rare and negligible in the SMB.

Most of the East Antarctic coast is characterised by a katabatic wind confluence area associated with snow transportation. Loewe (1972) pointed out that along Wilkes Land (George V Coast), blowing snow exports about $70 \times 10^{9} \mathrm{~kg} \mathrm{~km}^{-1}$ into the sea, which accounts for around
$30 \%$ of the Mertz, Ninnis and Cook Glacier's ice discharge. Satellite images of this area show very similar conditions to the Terra Nova Bay area, including surface condition (wind crust and blue ice area) and blowing snow phenomena (billows). SMB measurements in Adelie Land show that wind-driven processes are the largest contribution to ablation, removing much of the precipitation and showing very high interannual variability in SMB (Genthon et al. 2007).

The blowing snow phenomenon shows great variability over both spatial and temporal scales. The source site of snow transported toward measurement sites is dependent on the time required by the particle to sublimate in the wind flux once it is uplifted. Model simulations of sublimation processes (Taylor et al. 2006) on a plateau for particles of different radii $(50-250 \mu \mathrm{m})$ show that particles have short mean lives and are able to cover between 20 and $50 \mathrm{~km}$, depending on, $u$ in thermodynamic environments that simulate summer conditions. On the other hand, for late fall conditions, particles can travel up to $200 \mathrm{~km}$, because model sublimation rates are reduced with decreasing ambient temperature due to the reduction in vapour pressure (Pomeroy and Gray 1995). The analysis of snow $\delta^{18} \mathrm{O}$, performed every $5 \mathrm{~km}$ along the traverse Terra Nova Bay-Dome $\mathrm{C}$, shows that the sampled snow was not blown from far away but fell within few a tenths of a kilometre from the sample site (Proposito et al. 2002; Becagli et al. 2004).

On a temporal scale, snow transport is strongly related to the condition that wind flux exceeds threshold speed values, which depends on snow surface conditions and particle uplift. On the basis of these conditions, $64 \%$ of transport during 2007 occurred in the fall and winter seasons when the mean $u$ increased compared to the same periods of the previous year during which the residual 36\% of transport occurred. The AWS wind speed data for Mario Zucchelli Station (MZS) is in accordance with $u$ of ECMWF, and shows an increase of $10 \%$ in events of exceeding $5 \mathrm{~m} \mathrm{~s}^{-1}$ from 2006 to 2007.

Snow accumulation measurements from stake farms (more than 40 stakes in $4 \mathrm{~km}^{2}$ ) at two sites within the drainage basin area of the Terra Nova Bay glaciers (MidPoint: MdPt and Talos Dome: TD sites) show a decrease of 30\% in 2007 (MdPt: $33 \mathrm{~kg} \mathrm{~m}^{-2}$ year $^{-1}$, average 19982007: $47 \mathrm{~kg} \mathrm{~m}^{-2}$ year $^{-1}$; TD: $52 \mathrm{~kg} \mathrm{~m}^{-2}$ year $^{-1}$, average 2001-2007: $73 \mathrm{~kg} \mathrm{~m}^{-2}$ year $^{-1}$ ) with respect to 2006 values (MdPt $57 \mathrm{~kg} \mathrm{~m}^{-2}$ year $^{-1}$, TD $90 \mathrm{~kg} \mathrm{~m}^{-2}$ year $^{-1}$ ), whereas ECMWF analysis for both sites shows relatively constant precipitation through the 2 years. The observed increase in the wind regime in 2007 compared with 2006 causes enhanced snow transport/sublimation of up to $30 \%$. This in turn accounts for the same magnitude decrease in accumulation rate measured at different sites. 


\section{Conclusion}

Atmospheric model studies compute a mass divergence that tends to remove mass where ice sheet slope diverges and displace snowdrift deposition to coastal areas or convergence zones, with a balance that is close to nil.

Field and remote sensing analysis in the Terra Nova Bay and a similar site in East Antarctica (George V Coast) do not show any kind of snowdrift deposition as supposed by atmospheric model mass divergence/convergence parameterisation. Instead, there is an ablation surface (blue ice and wind crust) in the katabatic wind convergence area and downwind of it. Our instrumental observations (FlowCapt) integrated with previous snow accumulation survey (snow radar, firn core, remote sensing) suggest that the combined processes of blowing snow sublimation and snow transport remove (mainly in the atmosphere) up to $50 \%$ of precipitation in the coastal and slope convergence area. The observed wind-driven ablation explains the inconsistency between the atmospheric model precipitation (e.g., ECMWF) and the measured snow accumulation value.

Due to uncertainties in snow transportation, in particular stemming from high snow fluxes with particles transported up to $200 \mathrm{~m}$ above the earth's surface and limited instrumental accuracy, the presented evaluation must be considered first order quantitative and the lower bound value of snow transportation. The transport divergence is the most difficult term to estimate, and its modelled value can have large variation depending on which wind/transport relationship is used.

An increase in snow precipitation coupled with an increase in temperature and/or wind could increase the surface mass balance in the inner part of East Antarctica if it was considered alone. However, it could cause a significant decrease in surface mass balance in the windy areas that represent $90 \%$ of the East Antarctic surface. Recent studies point to wind-induced circulation changes in the ocean as the dominant cause of the recent ice losses through the draining of the glaciers on the ice sheet (Holland et al. 2008; Thoma et al. 2008). Both the use of numerical simulation to predict the ice sheet's contribution to sea level rise as well as remote sensing (GRACE, Radarlaser altimeter) measurements are significantly hampered by the lack of evaluation of wind-driven processes in ice sheet mass balances.

Blowing snow is also an important source of ocean freshening, and it should be taken into account particularly in the polynya area (Terra Nova Bay, George V Coast etc.). Jacobs et al. (2002) studied a freshening of the Ross Sea during the late 20th Century that appears to have resulted from a combination of factors, including increased precipitation. Although no increase in accumulation has been observed from atmospheric models or ice cores (Monaghan et al. 2006; Frezzotti et al. 2007), the observed freshening could be related to the increase of blowing snow from the continent to the coastal area.

Acknowledgments This research was carried out as part of the framework of the Project on Glaciology and Observatory of the PNRA-MIUR, and was financially supported by the PNRA Consortium through collaboration with ENEA and INGV Roma and Ice2sea Project funded by the EU FP7. Comments by two anonymous referees greatly improved the text.

Open Access This article is distributed under the terms of the Creative Commons Attribution Noncommercial License which permits any noncommercial use, distribution, and reproduction in any medium, provided the original author(s) and source are credited.

\section{References}

Agnoletto L (2009) Verifica dei modelli meteorologici: verifiche di punto e di area dei modelli operazionali a scala globale e mesoscala utilizzati per le previsioni meteorologiche in Antartide nella Terra Vittoria. Ph.D. Thesis, University of Siena

Anschutz H, Eisen O, Rack W, Scheinert M (2006) Periodic surface features in coastal East Antarctica. Geophys Res Lett 33:L22501. doi:10.1029/2006GL027871

Becagli S, Proposito M, Benassai S, Flora O, Genoni L, Gragnani R, Largiuni O, Pili SL, Severi M, Stenni B, Traversi R, Udisti R, Frezzotti M (2004) Chemical and isotopic snow variability in East Antarctica along the 2001/02 ITASE traverse. Ann Glaciol 39:473-482. doi:10.3189/172756404781814636

Bintanja R (1998) The contribution of snowdrift sublimation to the surface mass balance of Antarctica. Ann Glaciol 27:251-259

Bintanja R (2001) Modification of the wind speed profile caused by snowdrift: result from observations. Q J Meteorol Soc 127:24172434. doi:10.1002/qj.49712757712

Bintanja R, Reijmer CH (2001) A simple parameterization for snowdrift sublimation over Antarctic snow surfaces. J Geophys Res 106(D23):31739-31748. doi:10.1029/2000JD000107

Bromwich DH, Parish TR, Zorman CA (1990) The confluence zone of the intense katabatic winds at Terra Nova Bay, Antarctica, as derived from airborne sastrugi surveys and mesoscale numerical modelling. J Geophys Res 95(D5):5495-5509. doi:10.1029/JD09 5iD05p05495

Budd WF (1966) The drifting of non-uniform snow particles. In: Rubin MJ (ed) Studies in Antarctic meteorology. Antarctic research series, vol 9. American Geophysical Union, Washington, DC, pp 59-70

Budd WF, Dingle WR, Radok U (1966) The Byrd snow drift project: outline and basic results. AGU Antarct Res Ser 9:51-134

Chritin V, Bolognesi R, Gubler H (1999) FlowCapt: a new acoustic sensor to measure snow drift and wind velocity for avalanche forecasting. Cold Reg Sci Technol 30:125-133. doi:10.1016/S01 65-232X(99)00012-9

Cierco FX, Naaim-Bouvet F, Bellot H (2004) Snow transport rate: field measurements at short time scales. In: Proceedings of international snow science workshop, Jackson Hole, 19-24 September 2004

Cierco FX, Naaim-Bouvet F, Bellot H (2007) Acoustic sensors for snowdrift measurements: how should they be used for research purposes? Cold Reg Sci Technol 49:74-87. doi:10.1016/j. coldregions.2007.01.002 
Cullather RI, Bromwich DH, Grumbine RW (1997) Validation of operational numerical analyses in Antarctic latitudes. J Geophys Res 102(D12):13761-13784. doi:10.1029/96JD03328

Déry SJ, Yau MK (2001) Simulation of an Arctic ground blizzard using a coupled blowing snow-atmosphere model. J Hydrometeorol 2:579-598. doi:10.1175/1525-7541(2001)002<0579: SOAAGB $>2.0 . \mathrm{CO} ; 2$

Déry SJ, Yau MK (2002) Large-scale mass balance effects of blowing snow and surface sublimation. J Geophys Res 107(D23):4679. doi:10.1029/2001JD001251

Déry SJ, Taylor PA, Xiao J (1998) The thermodynamic effects of sublimating, blowing snow in the atmospheric boundary layer. Boundary Layer Meteorol 89:251-283. doi:10.1023/A:10017 12111718

Frezzotti M, Tabacco IE, Zirizzotti A (2000) Ice discharge of eastern dome C drainage area, Antarctica, determined from airborne radar survey and satellite image, analysis. J Glaciol 46:253-264. doi:10.3189/172756500781832855

Frezzotti M, Gandolfi S, La Marca F, Urbini S (2002a) Snow dune and glazed surface in Antarctica: new field and remote sensing data. Ann Glaciol 34:81-88. doi:10.3189/172756402781817851

Frezzotti M, Gandolfi S, Urbini S (2002b) Snow megadune in Antarctica: sedimentary structure and genesis. J Geophys Res 107(D18):4344. doi:10.1029/2001JD000673

Frezzotti M, Pourchet M, Flora O, Gandolfi S, Gay M, Urbini S, Vincent C, Becagli S, Gragnani R, Proposito M, Severi M, Traversi R, Udisti R, Fily M (2004) New estimations of precipitation and surface sublimation in East Antarctica from snow accumulation measurements. Clim Dyn 23:7-8. doi: 10.1007/s00382-004-0462-5

Frezzotti M, Pourchet M, Flora O, Gandolfi S, Gay M, Urbini S, Vincent C, Becagli S, Gragnani R, Proposito M, Severi M, Traversi R, Udisti R, Fily M (2005) Spatial and temporal variability of snow accumulation in East Antarctica from traverse data. J Glaciol 51(172):113-124. doi:10.3189/1727565 05781829502

Frezzotti M, Urbini S, Proposito M, Scarchilli C, Gandolfi S (2007) Spatial and temporal variability of surface mass balance near Talos Dome, East Antartica. J Geophys Res 112:F02032. doi: 10.1029/2006JF000638

Gallée H, Guyomarch G, Brun E (2001) Impact of snow drift on the Antarctic Ice Sheet surface mass balance: possible sensitivity to snow-surface properties. Boundary Layer Meteorol 99:1-19. doi: 10.1023/A: 1018776422809

Gallée H, Peyaud V, Goodwin I (2005) Simulation of the net snow accumulation along the Wilkes Land transect, Antarctica, with a regional climate model. Ann Glaciol 41:17-22. doi:10.3189/ 172756405781813230

Genthon C, Krinner G (2001) The Antarctic surface mass balance and systematic biases in GCMs. J Geophys Res 106:20653-20664

Genthon C, Krinner G, Sacchettini M (2003) Interannual Antarctictropospheric circulation and precipitation variability. Clim Dyn 21:289-307. doi:10.1007/s00382-003-0329-1

Genthon C, Lardeux P, Krinner G (2007) The surface accumulation and ablation of a coastal blue-ice area near Cap Prudhomme, Adélie Land, Antarctica. J Glaciol 53(183):635-645. doi:10.3189/ 002214307784409333

Holland DM, Thomas RH, de Young B, Ribergaard MH, Lyberth B (2008) Acceleration of Jakobshavn Isbræ triggered by warm subsurface ocean waters. Nat Geosci 1:659-664. doi:10.1038/ ngeo316

Jacobs SS, Giulivi CF, Mele PA (2002) Freshening of the Ross Sea during the late 20th century. Science 297:386-389. doi:10.1126/ science. 1069574
Jaedicke C (2001) Acoustic snowdrift measurements: experiences from FlowCapt instrument. Cold Reg Sci Technol 32:71-81. doi: 10.1016/S0165-232X(01)00017-9

Kodama Y, Wendler G, Gosink J (1985) The effect of blowing snow on katabatic winds in Antarctica. Ann Glaciol 6:59-62

Krinner G, Magand O, Simmonds I, Genthon C, Dufresne JL (2007) Simulated Antarctic precipitation and surface mass balance at the end of the twentieth century. Clim Dyn 28:215-230. doi: 10.1007/s00382-006-0177-x

Lehning M, Naaim F, Brabec B, Doorschot J, Durand Y, Guyomarch G, Michaux JL, Zimmerli M (2002) Snowdrift: acoustic sensors for avalanche warning and research. Nat Hazards Earth Syst Sci 2:121-128

Loewe F (1972) The land of storms. Weather 27:110-121

Loewe F (1974) Considerations concerning the winds of Adelie Land. Z Gletsch kd Glazialgeol 10:189-197

Mahesh A, Eagen R, Campbell JR, Spinhirne D (2003) Observation of blowing snow at the South Pole. J Geophys Res 180(D22):4707. doi:10.1029/2002JD003327

Mann GW (1998), Surface heat and water vapour budges over Antarctica. Ph.D. Thesis, Environment Centre, University of Leeds, Leeds, pp 279

Mann GW, Anderson PS, Mobbs SD (2000) Profile measurements of blowing snow at Halley, Antarctica. J Geophys Res 105(D19):24491-24508. doi:10.1029/2000JD900247

Monaghan AJ, Bromwich DH, Fogt RL, Wang SH, Mayewski PA, Dixon DA, Ekaykin A, Frezzotti M, Goodwin I, Isaksson E, Kaspari SD, Morgan VI, Oerter H, van Ommen T, van der Veen CJ, Wen J (2006) Insignificant change in Antarctic snowfall since the international geophysical year. Science 313:827-831. doi:10.1126/science. 1128243

Nishimura K, Nemoto M (2005) Blowing snow at Mizuho station, Antarctica. Phil Trans R Soc 363:1647-1662. doi:10.1098/rsta. 2005.1599

Pettré P, Pinglot JF, Pourchet M, Reynaud L (1986) Accumulation distribution in Terre Adélie, Antarctica: effect of meteorological parameters. J Glaciol 32(112):486-500

Pomeroy JW (1988) Wind transport of snow. Ph.D. Thesis, Division of Hydrology, University of Saskatchewan, Saskatoon, pp 226

Pomeroy JW, Gray DM (1995) Snow cover accumulation, relocation and management. NHRI Science report No. 7, Saskatoon, pp 144

Proposito M, Becagli S, Castellano E, Flora O, Gragnani R, Stenni B, Traversi R, Udisti R, Frezzotti M (2002) Chemical and isotopic snow variability along the 1998 ITASE traverse from Terra Nova Bay to DC (East-Antarctica). Ann Glaciol 35:187-194. doi: 10.3189/172756402781817167

Schmidt RA (1982) Vertical profiles of wind speed, snow concentration and humidity in blowing snow. Boundary Layer Meteorol 23(2):223-246. doi:10.1007/BF00123299

Shiotanai M, Arai H (1967) On vertical distribution of blowing snow. In: Oura H (ed) Physics of snow and ice. Part 2, vol 1. Hokkaido University, Institute of Low Temperature Science, Sapporo, pp 1075-1083

Stenni B, Serra F, Frezzotti M, Maggi V, Traversi R, Becagli S, Udisti $R$ (2000) Snow accumulation rates in Northern Victoria Land (Antarctica) by firn core analysis. J Glaciol 46(155):541-552. doi: $10.3189 / 172756500781832774$

Takahashi S (1985) Characteristics of drifting snow at Mizuho Station, Antarctica. Ann Glaciol 6:71-75

Taylor PA, Baibakov K, Brown S, Hecht MH, Hudson TL, Li PY, Lange CF, Prieto L, Savelyev S (2006) On the sublimation of ice particle on the surface of Mars; with applications to the 2007/8 Phoenix Scout Mission. Icarus 181:375-387. doi:10.1016/j. icarus.2005.10.031 
Thoma M, Jenkins A, Holland D, Jacobs S (2008) Modelling circumpolar deep water intrusions on the Amundsen sea continental shelf, Antarctica. Geophys Res Lett 35:L18602. doi: 10.1029/2008GL034939

van den Broeke M, van de Berg WJ, van Meijgaard E, Reijmer C (2006) Identification of Antarctic ablation areas using a regional atmospheric climate model. J Geophys Res 111:D18110. doi: 10.1029/2006JD007127

Van Woert ML, Meier WN, Zou CZ, Archer A, Pellegrini A, Grigioni P, Bertola C (2001) Satellite observations of upper-ocean currents in Terra Nova Bay, Antarctica. Ann Glaciol 33:407412. doi:10.3189/172756401781818879

Wendler G, André JC, Pettré P, Gosink J, Parish T (1993) Katabatic winds in Adélie Coast. In: Bromwich DH, Stearns CR (eds) Antarctic meteorology and climatology: studies based on automatic weather stations. American Geophysical Union, Washington. Antarctic Res Ser 61:23-46

Zibordi G, Frezzotti M (1996) Orographic clouds in north Victoria Land from AVHRR images. Polar Rec (Gr Brit) 32(183):317324 